\title{
SNPing away at mutant p53 activities
}

\author{
Guadalupe J. Ortiz and Guillermina Lozano \\ Department of Genetics, The University of Texas MD Anderson Cancer Center, Houston, Texas 77030, USA
}

\begin{abstract}
A delicate balance in the levels of proteins that regulate the p53 tumor suppressor pathway exists such that subtle changes alter $\mathrm{p} 53$ tumor suppressor activity and cancer risk. Many single-nucleotide polymorphisms (SNPs) in the p53 pathway alter p53 transcriptional activity and are associated with cancer risk. In addition, some SNPs influence the gain-of-function (GOF) activities of mutant p53 through unknown mechanisms. In this issue of Genes \& Development, Basu and colleagues (pp. 230-243) provide direct evidence that the presence of an $R 72$ polymorphism enhances the GOF invasive and metastatic properties of mutant 533 by regulating interactions with PGC-1 $\alpha$, an important regulator of mitochondrial biogenesis and oxidative phosphorylation. The study culminates with evidence that $R 72$ is associated with worse outcomes in human breast cancer.
\end{abstract}

The p53 tumor suppressor pathway includes many proteins that regulate 553 transcriptional activity (Kim and Lozano 2018). Subtle variations in the levels of these proteins affect p53 function as a tumor suppressor (Eischen and Lozano 2014). For example, the difference in p53 protein levels between mice harboring one or two copies of a hypomorphic $p 53$ allele is $7 \%$, yet these models exhibit significant differences in survival. In addition, minor changes in the levels of $\mathrm{Mdm} 2$ and Mdm4, potent p53 inhibitors, influence survival in mice under stress conditions. $\mathrm{Mdm2^{+/- }}$ and $\mathrm{Mdm4^{+/- }}$ mice are normal but become radiosensitive and die upon exposure to a sublethal dose of ionizing radiation (Eischen and Lozano 2014).

Single-nucleotide polymorphisms (SNPs) also have subtle effects on p53 function. Mice harboring the $M d m 2 S N P 309 G$ allele are more prone to spontaneous tumor development compared with Mdm2SNP309T mice (Post et al. 2010). The SP1 transcription factor preferably binds to the SNP309G variant and enhances the levels of $M d m 2$, ultimately dampening p53 activity and increasing cancer risk. However, additional studies in SNP309 mice challenged with environmental stress factors, such as low-dose ionizing radiation (IR), ultraviolet light, or benzo(a)pyrene, showed contrasting differences in vulner-

[Keywords: mutant p53; codon 72; metastasis; oxidative phosphorylation; PGC-1 $\alpha$ ]

Corresponding author: gglozano@mdanderson.org

Article is online at http://www.genesdev.org/cgi/doi/10.1101/gad.312934. 118 . ability to skin cancer risk (Ortiz et al. 2018). In this context, SNP309G was bound by the E2F6 transcriptional inhibitor, which decreased $M d m 2$ levels and thus increased p53 levels and reduced the risk of skin cancer. These data indicate that SNPs can be multidimensional regulators in a context-dependent manner with sometimes opposing impact on cancer risk.

These in vivo experiments provide direct evidence of the role of p53 pathway SNPs on cancer risk. These same SNPs and others in the TP53 gene (the International Agency for Research on Cancer [IARC] TP53 Mutation Database lists 85 common polymorphisms) exist in humans, and some are associated with cancer risk. For example, $S N P 309 G$ is associated with increased cancer risk in Li Fraumeni syndrome patients with TP53 mutations (Bond et al. 2004). A SNP in TP53 codon 72 encodes either a proline (P72) or arginine (R72) amino acid and alters p53 protein function in various scenarios (Basu and Murphy 2016).

SNP72 has also been studied in the context of mutant p53. R72 enhances mutant p53 gain of function (GOF) by preferably binding and attenuating p 73 activity as compared with P72 in cell lines (Marin et al. 2000). In addition, a small cohort of squamous cell carcinoma tumors heterozygous for codon 72 retains $\mathrm{R} 72$, suggesting a contribution of R72 to tumor progression (Marin et al. 2000).

In their study, Basu et al. (2018) asked how SNP72 impacted mutant p53 GOF phenotypes. To address this tantalizing question, the investigators generated three isogenic cell lines, each with three different p53 mutations with either P72 or R72 amino acids, and evaluated the impact of $S N P 72$ on GOF phenotypes such as invasion and migration in multiple assays. They then validated their findings in a pair of tumor cell lines with endogenous mutant $\mathrm{p} 53$. The data clearly show that cell lines harboring mutant p53 proteins with R72 have increased migration and invasion compared with P72 cell lines. Notably, knockdown of mutant p53 eliminated the differences between isogenic cell lines. In vivo studies in NOD scid $\gamma$ (NSG) mice also show that mutant p53 with R72 exacerbated lung and bone metastases compared with mutant p53 mice carrying P72.

(C) 2018 Ortiz and Lozano This article is distributed exclusively by Cold Spring Harbor Laboratory Press for the first six months after the full-issue publication date (see http://genesdev.cshlp.org/site/misc/terms.xhtml). After six months, it is available under a Creative Commons License (Attribution-NonCommercial 4.0 International), as described at http:// creativecommons.org/licenses/by-nc/4.0/. 
To elucidate the mechanism by which SNP72 impacted p53 GOF, the investigators examined known contributors to the GOF properties of mutant $\mathrm{p} 53$ (inhibition of p 63 and $\mathrm{p} 73$, for example) but did not find any differences in the impact of the polymorphism on p53 mutant phenotypes. Subsequently, the investigators performed an RNA sequencing analysis and identified a significant association with oxidative phosphorylation and mitochondrial pathways as well as a significant increase in genes regulated by PGC-1 $\alpha$. PGC-1 $\alpha$ is a transcriptional coactivator of mitochondrial biogenesis (Schmidt and Mandrup 2011). Studies show that PGC-1 $\alpha$ uses a network of transcriptional regulators that alter metabolic function, including oxidative phosphorylation. Basu et al. (2018) present evidence that mutant p53 directly binds with PGC- $1 a$ and that mutant p53 proteins with R72 bind PGC-1a less well (Fig. 1). Thus, cells with R72 mutant p53 have an increase in free PGC- $1 \alpha$ and adapt more readily to changes in nutrient level. This novel finding provides a mechanistic basis for how tumor-derived p53 mutants contribute to the metabolic needs of the tumor cell. Down-modulating the levels of PGC-1 1 decreased cell invasion. It is important to note, however, that mutant p53 interactions with PGC-1 $\alpha$ do not account for all GOF activities of mutant p53. SREBP and ETS2 transcription factors impact p53 GOF in many other studies and may contribute to the effects of SNP72 on mutant p53 activities (Kim and Lozano 2018). Human studies in breast cancer data sets show that patients harboring mutant p53 with R72 show a worse prognosis compared with patients with mutant p53 and P72. Ultimately, the levels of PGC-1 $\alpha$ present in specific cell types will influence the aggressiveness of tumors that develop.

Many questions remain to be addressed. PGC- $1 \alpha$ is a member of a large family of proteins that are highly related, and PGC-1 $a$ itself has multiple isoforms (Schmidt and Mandrup 2011). Do these proteins contribute to or compete with PGC-1a binding to mutant p53? Phosphoryla-



Figure 1. Cell lines with mutant p53 with codon R72 have increased oxidative phosphorylation (OXPHOS), which enhances the invasive and metastatic GOF activities of mutant p53. Mutant p53 with codon R72 does not bind PGC-1 $\alpha$ well, allowing PGC-1 $\alpha$ to interact with other transcription factors to increase oxidative phosphorylation, leading to increased invasion and metastasis. On the other hand, mutant p53 with codon P72 interacts well with PGC-1a, limiting its availability for oxidative phosphorylation and consequently limiting mutant p53 GOF activity. tion of PGC-1 $\alpha$ also regulates its activity (Schmidt and Mandrup 2011). Does phosphorylation impact interactions with mutant $\mathrm{p} 53$ ? What levels of PGC-1 1 are needed to see increased invasion and metastatic phenotypes? Likely, p53 mutant cells with very high levels of PGC1a may have sufficient PGC-1a to adapt to its metabolic needs, since the effect on invasion and metastasis is dependent on sequestering PGC-1a. How much mutant p53 is in the cell matters as well. Differences between mutant p53 alleles also exist. Is the transcriptional activation function of $\mathrm{p} 53$ required for this effect on invasion and metastasis? More importantly, is disruption of mutant p53 interactions with PGC-1a sufficient to decrease invasion and metastasis in patient tumors and improve outcome? In closing, Basu et al. (2018) show evidence that R72 enhances mutant p53 interactions with PGC-1a to worsen tumor outcome. Further understanding of the influence of SNPs within the p53 pathway could facilitate the understanding of tumor progression and potentially provide new insight into the development of prognostic and therapeutic cancer modalities.

\section{Acknowledgments}

This work was supported by National Institutes of Health grant CA47296 (to G.L.).

\section{References}

Basu S, Murphy ME. 2016. Genetic modifiers of the p53 pathway. Cold Spring Harb Perspect Med 6: a026302.

Basu S, Gnanapradeepan K, Barnoud T, Kung C-P, Tavecchio M, Scott J, Watters A, Chen Q, Kossenkov AV, Murphy ME. 2018. Mutant p53 controls tumor metabolism and metastasis by regulating PGC-1a. Genes Dev (this issue). 10.1101/ gad.309062.117.

Bond GL, Hu W, Bond EE, Robins H, Lutzker SG, Arva NC, Bargonetti J, Bartel F, Taubert H, Wuerl P, et al. 2004. A single nucleotide polymorphism in the MDM2 promoter attenuates the p53 tumor suppressor pathway and accelerates tumor formation in humans. Cell 119: 591-602.

Eischen CM, Lozano G. 2014. The Mdm network and its regulation of p53 activities: a rheostat of cancer risk. Hum Mutat 35: 728-737.

Kim MP, Lozano G. 2018. Mutant p53 partners in crime. Cell Death Differ 25: 161-168.

Marin MC, Jost CA, Brooks LA, Irwin MS, O'Nions J, Tidy JA, James N, McGregor JM, Harwood CA, Yulug IG, et al. 2000. A common polymorphism acts as an intragenic modifier of mutant p53 behaviour. Nat Genet 25: 47-54.

Ortiz GJ, Li Y, Post SM, Pant V, Xiong S, Larsson CA, El-Naggar AK, Johnson DG, Lozano G. 2018. Contrasting effects of an $\mathrm{Mdm} 2$ functional polymorphism on tumor phenotypes. Oncogene 37: 332-340.

Post SM, Quintas-Cardama A, Pant V, Iwakuma T, Hamir A, Jackson JG, Maccio DR, Bond GL, Johnson DG, Levine AJ, et al. 2010. A high-frequency regulatory polymorphism in the p53 pathway accelerates tumor development. Cancer Cell 18: 220-230.

Schmidt SF, Mandrup S. 2011. Gene program-specific regulation of PGC-1a activity. Genes Dev 25: 1453-1458. 


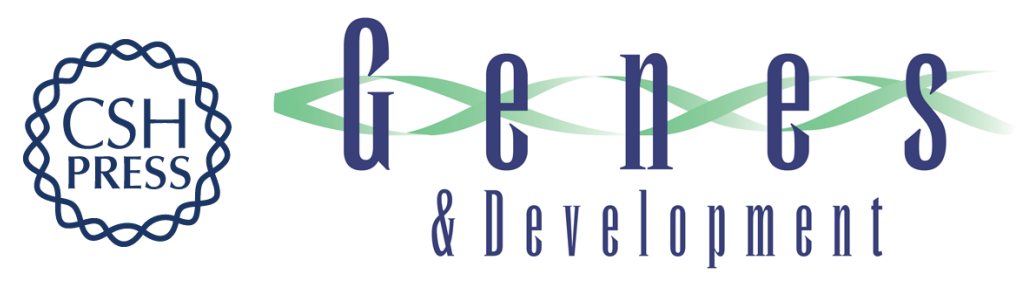

\section{SNPing away at mutant p53 activities}

Guadalupe J. Ortiz and Guillermina Lozano

Genes Dev. 2018, 32:

Access the most recent version at doi:10.1101/gad.312934.118

Related Content Mutant p53 controls tumor metabolism and metastasis by regulating PGC-1士 Subhasree Basu, Keerthana Gnanapradeepan, Thibaut Barnoud, et al. Genes Dev. February , 2018 32: 230-243

References This article cites 9 articles, 3 of which can be accessed free at: http://genesdev.cshlp.org/content/32/3-4/195.full.html\#ref-list-1

Articles cited in:

http://genesdev.cshlp.org/content/32/3-4/195.full.html\#related-urls

Creative This article is distributed exclusively by Cold Spring Harbor Laboratory Press for the first Commons License six months after the full-issue publication date (see http://genesdev.cshlp.org/site/misc/terms.xhtml). After six months, it is available under a Creative Commons License (Attribution-NonCommercial 4.0 International), as described at http://creativecommons.org/licenses/by-nc/4.0/.

Email Alerting Receive free email alerts when new articles cite this article - sign up in the box at the top Service right corner of the article or click here.



